\title{
A Prospective Study on Prevalence of Helicobacter pylori in Our Endoscopic Centre
}

\author{
Chawngthu Vanlalhlua ${ }^{1}$, Rachel Lalramlawmi ${ }^{2}$ \\ ${ }^{1}$ Associate Professor, Department of General Surgery, ${ }^{2}$ Medical Officer and Endoscopist, Department of General Surgery, \\ Zoram Medical College, Falkawn, Mizoram, N.E., India
}

Corresponding author: Dr Chawngthu Vanlalhlua, M.S, FAIS, FMAS, EFIAGES, Associate Professor, Department of General Surgery, Zoram Medical College, Falkawn, Mizoram, N.E., India

DOI: http://dx.doi.org/10.21276/ijcmsr.2020.5.1.2

(c) BY-NC-ND

How to cite this article: Chawngthu Vanlalhlua, Rachel Lalramlawmi. A prospective study on prevalence of helicobacter pylori in our endoscopic centre. International Journal of Contemporary Medicine Surgery and Radiology. 2020;5(1):A6-A9.

\section{A B S T R A C T}

Introduction: Abdominal pain is one of the most common symptoms in patients referred for Upper Gastrointestinal (UGI) Endoscopy examination in our centre. Helicobacter pylori is a gram-negative, helically shaped, microaerophilic bacterium usually found in the stomach, and is associated with peptic ulcer disease and gastric malignancy. The aim of this study was to find out the prevalence of $\mathrm{H}$. pylori among our patients.

Material and Methods: This study comprised of 5910 patients referred from various departments to our Endoscopy centre, who had undergone UGI Endoscopy during the period of 2 years at Zoram Medical College starting from November 2017 to October 2019. All patients referred for Endoscopy were included. Age ranges from 8 years to 92 years old. UGI Endoscopy was performed by Endoscopist/Surgeons in all subjects as a primary diagnostic investigation and interpretation of the findings as observed by a single observer was noted. Rapid Urease test was done in almost all the cases.

Results: Helicobacter pylori infection was found in $24.95 \%$ of total cases. It is found that majority of patients with Duodenitis $(78.67 \%)$ and Ulcers of stomach $(77.11 \%)$ were found to be positive for $\mathrm{H}$. pylori thereby underlying its significance in their etiology. In cases of reflux esophagitis alone, only 12 cases out of 1062 (1.21\%) were found positive. 31 cases of 218 normal endoscopic study shows Helicobacter pylori test positive.

Conclusion: We conclude that Investigation for $\mathrm{H}$. pylori should be considered for all patients undergoing endoscopy especially those who have gastric or duodenal lesions and other chronic medical problems as its association with these conditions are higher.

Keywords: Endoscopy, Helicobacter pylori, Erosions/Erythema, Ulcers, Varices.

\section{INTRODUCTION}

Helicobacter pylori (i.e H. pylori), previously known as Campylobacter, is a gram-negative, helically shaped, microaerophilic bacterium usually found in the stomach. ${ }^{1}$ Its helical shape (from which the genus name, helicobacter, derives) is thought to have evolved in order to penetrate the mucoid lining of the stomach and thereby establish infection. ${ }^{2}$ The bacterium was first identified in 1982 by Australian doctors Barry Marshall and Robin Warren, who found that it was present in a person with chronic gastritis and gastric ulcers, conditions not previously believed to have a microbial cause. . $^{3,4}$

H. pylori has also been linked to the development of duodenal ulcers, polyp, i.e benign growth, in the small intestine, large intestine, and rectum, and malignancies of the stomach's secretory glands (termed stomach adenocarcinoma) ${ }^{6}$, of the mucosa-associated lymphoid tissue in the stomach, esophagus, colon, rectum, or tissues around the eye (termed extranodal marginal zone B-cell lymphoma of the cited $\operatorname{organ}^{7,8,9}$ and of lymphoid tissue in the stomach (termed diffuse large B-cell lymphoma). ${ }^{10}$

Patients with pain upper abdomen constitute majority of patients referred for UGI Endoscopy. Although a detailed history and physical examination may help to arrive at diagnosis, most of the times it is difficult to do so considering the complexity of the abdominal anatomy. Routine investigations only have a subordinate role and results of Ultrasonography are limited by intestinal gas. ${ }^{11} \mathrm{Within}$ the invention of fiberoptic glasses flexible endoscopy, upper GI endoscopy has become a safe, reliable and office procedure. With further advancements in narrow band imaging and chromoendoscopy, precision of biopsy techniques and diagnosis has been significantly increased. ${ }^{12}$ Discovery of role of Helicobacter pylori in the pathogenesis of gastric and duodenal ulcers was a breakthrough in the treatment of these lesions. Since then a variety of invasive and non-invasive tests are available to diagnose H. pylori infection. ${ }^{13}$

Endoscopy is a sensitive diagnostic test for peptic ulcers. Endoscopy was more sensitive (92\%vs 54\%) and more specific (100\%vs 91\%) than radiographic examination. ${ }^{14}$ The main role of Endoscopy in patients with uncomplicated peptic 
ulcer diseases is to confirm the diagnosis, identify lesions too small to be detected by radiolographic examination and to rule out malignancy by performing endoscopic biopsy. ${ }^{15}$ Detection of $\mathrm{H}$. pylori infection using a simple Urease test kit of gastric mucosa by Endoscopy biopsy forcep became popular and easily available. This study aimed to find out the prevalence of H.P infection among patients in our Endoscopy centre.

\section{MATERIAL AND METHODS}

This prospective observational study was conducted in the department of Surgery Endoscopy centre, State Referral Hospital of Zoram Medical College, Falkawn, and LRM Hospital, Aizawl, Mizoram during the periods of two years starting from November 2017 to October 2019. All patients of both sexes referred for UGI Endoscopy totaling 5910 consecutive cases were included; their age ranges from 8years to 92 years old. Before taking up the study, approval for carrying out the research work was obtained from the Hospital Ethical Committee. Informed Consent was taken for each case. Endoscopy biopsy was taken for rapid urease testing.

\begin{tabular}{|l|c|c|}
\hline Age group & No. patients & Percentage \\
\hline$<20$ yrs & 532 & $9 \%$ \\
\hline $21-30$ & 1300 & $22 \%$ \\
\hline $31-40$ & 1418 & $24 \%$ \\
\hline $41-50$ & 1123 & $19 \%$ \\
\hline $51-60$ & 709 & $12 \%$ \\
\hline $61-70$ & 473 & $8 \%$ \\
\hline $71-80$ & 296 & $5 \%$ \\
\hline$>80$ yrs & 59 & $1 \%$ \\
\hline Total & 5910 & $100 \%$ \\
\hline \multicolumn{2}{|c|}{ Table-1: Age group distribution. } \\
\hline
\end{tabular}

\begin{tabular}{|l|c|c|}
\hline Sex Distribution & No. of Patients & Percentage \\
\hline Male & 3220 & $54.48 \%$ \\
\hline Female & 2690 & $45.52 \%$ \\
\hline Total & 5910 & $100 \%$ \\
\hline \multicolumn{2}{|c|}{ Table-2: Sex distribution } \\
\hline
\end{tabular}

\begin{tabular}{|c|c|c|c|}
\hline Endoscopy Findings & $\begin{array}{l}\text { No Cases and } \\
\text { its Percentage }\end{array}$ & $\begin{array}{c}\text { No of HP } \\
\text { Positive and \% }\end{array}$ & $\begin{array}{l}\% \text { of HP } \\
\text { positive }\end{array}$ \\
\hline Gastro-Esophageal Reflux Esophagitis (Erosions/erythema) & $1062(17.96 \%)$ & $\begin{array}{c}12 \\
(1.12 \%)\end{array}$ & $0.81 \%$ \\
\hline Erosive or Erythematous Gastritis (Fundal/Antral/Body) & $3485(58.96 \%)$ & $\begin{array}{c}632 \\
(18.13 \%) \\
\end{array}$ & $42.84 \%$ \\
\hline Erosive/Erythematous Duodenitis & $\begin{array}{c}605 \\
(10.23 \%) \\
\end{array}$ & $\begin{array}{c}476 \\
(78.67 \%)\end{array}$ & $32.27 \%$ \\
\hline Ulcers/Growths/Polyps etc (Stomach/Duodenum) from where Biopsy taken & $\begin{array}{c}402 \\
(6.80 \%)\end{array}$ & $\begin{array}{c}310 \\
(77.11 \%)\end{array}$ & $21.01 \%$ \\
\hline Esophageal Varices of various grades & $\begin{array}{c}138 \\
(2.33 \%)\end{array}$ & $\begin{array}{c}14 \\
(10.14 \%)\end{array}$ & $0.95 \%$ \\
\hline Normal study & $\begin{array}{c}218 \\
(3.69)\end{array}$ & $\begin{array}{c}31 \\
(14.22 \%) \\
\end{array}$ & $2.10 \%$ \\
\hline Total & 5910 & $1475(24.95 \%)$ & $100 \%$ \\
\hline
\end{tabular}

H. pylori test was done using RUT (Rapid Urease Test) DRY test. The test kit was stored at room temperature and should not be freeze. A small mucosal tissue was taken from gastric Antrum near pyloric orifice using Endoscopy biopsy forcep. The standard biopsy size is $2-3 \mathrm{~mm}$ diameter. Test kit label was peeled back and tissue was introduced in the exposed yellow media and one drop of distilled sterile water was added. After covering sticker as before, the color change from yellow to pink or red was noted as positive for $\mathrm{H}$. pylori. Reading was done within 2 to 10 minutes (intervals time 4 hours) by observing color change from yellow to pink or red. The other endoscopic findings were also noted, recorded and reported.

\section{RESULTS}

This study includes all patients referred to our Endoscopy centre of varying ages ranging from $8 y$ rs to $92 y r s$ of age with the maximum number in the age groups of 31-40 yrs of as shown in the table I. We had 3 cases of below 11 years old$8 \mathrm{yrs}, 9 \mathrm{yrs}$, and $10 \mathrm{yrs}$ each and two 2 cases of more than $90 \mathrm{yrs}$ old $-91 \mathrm{yrs}$ and 92 years each. This study comprised of $54.48 \%$ male and $45.52 \%$ females (table-2).

It is found from the table III and graph-1 that majority of patients with Duodenitis (78.67\%) and Ulcers of upper GI tract $(77.11 \%)$ were found to be positive for $\mathrm{H}$. pylori thereby underlying its significance in their etiology. In cases of reflux

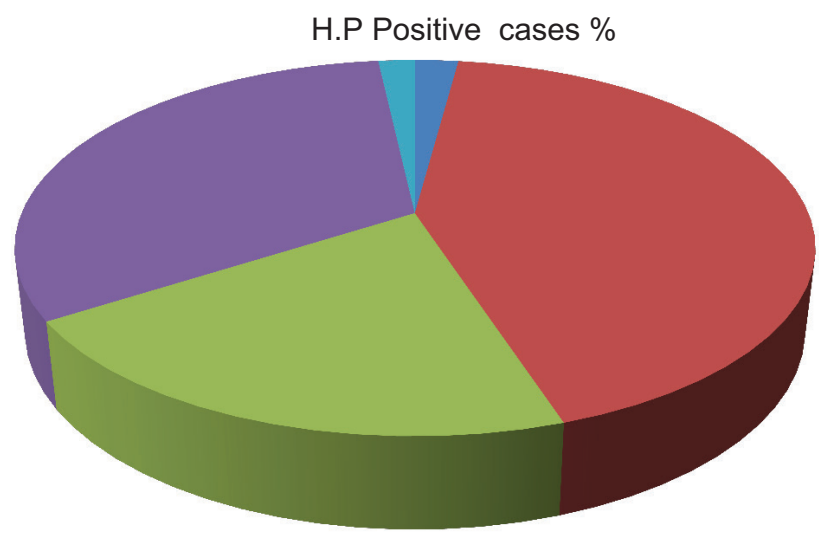

Normal Gastritis Ulcers Duodenitis Others

Graph-1: HP positivity in different Endoscopic findings 
esophagitis alone, only 12 cases out of 1062 (1.21\%) were found positive. Most of the cases were tested for Helicobacter pylori except in few cases of Esophageal Varices for fear of bleeding due to mucosal tear, out of 138 cases of Esophageal Varices, 14 cases $(10.14 \%)$ were found to be $H$.pylori positive and in 218 normal study cases, 31 cases (14,22\%) were found to be $\mathrm{H}$. pylori positive.

\section{DISCUSSION}

Our study showed the overall prevalence of $\mathrm{H}$ pylori is $24.95 \%$ in all the cases referred for Upper GI endoscopy for various reasons in our centre. At least half the world's population is infected by the bacterium, making it the most widespread infection in the world. Actual infection rates vary from nation to nation; the developing world has much higher infection rates than the west (Western Europe, North America, Australasia), where rates are estimated to be around $25 \% .{ }^{16}$ This may correspond to our findings as all the cases are not tested due to certain reasons like Varices, portal hypertension and normal endoscopic findings.

It is found from the table III that majority of patients with Duodenitis (78.67\%) and Ulcers of upper GI tract (77.11\%) were found to be positive for $\mathrm{H}$ pylori thereby underlying its significance in their etiology. This finding corresponds to the study by Arunabha et $\mathrm{al}^{17}$ where more than $80 \%$ of patients with gastric/duodenal lesions were infected with Helicobacter pylori.

The prevalence of HP infection is high, ranging from 20.6\% to $73 \%$ in haemodialysis patients. ${ }^{18}$ Another study shows H.P was detected in $62.5 \%$ of the patients with gastroduodenal lesions and it is the single most factor for dyspepsia in uremic patients. ${ }^{19}$ The possible explanations for higher prevalence are presence of urease enzyme and impaired immune system function. Urease constitutes $10 \%$ of total protein and is highly substrate dependent. ${ }^{20}$ Urease splits urea into ammonia and bicarbonate. Ammonia by promoting alkaline environment facilitates the survival and growth in acidic medium. HP makes use of ammonia for aminoacid synthesis and ammonia by cytotoxic effect on gastric epithelial cell promotes virulence of bacteria. There are alternative routes via amidase for ammonia production. ${ }^{21}$ Bicarbonate antagonizes the bactericidal effect of peroxynitrite, a nitric oxide metabolite. ${ }^{22}$ The other explanations are impaired gastric blood supply, sluggish gastric motility, hypo and hyperchlorhydria ${ }^{23}$ and immune dysfunction. ${ }^{24}$

There are studies showing lower prevalence of $\mathrm{HP}$ in Chronic Kidney Disease patients ${ }^{25,26}$, main reason being implicated are the bactericidal effect of commonly used antibiotics and their higher concentration in renal failure. This has a negative impact in the survival of Helicobacter pylori. ${ }^{27}$ In another study ${ }^{28}$, endoscopic findings were abnormal in 63\% patients with chronic kidney disease showing Antral gastritis in 42\% and Duodenitis in $24 \%$ which is in concordance with our findings.

\section{CONCLUSION}

The prevalence of $\mathrm{H}$. pylori infection in our centre is about one fourth of the total Endoscopy cases. We concluded that investigating Helicobacter pylori should be considered for all patients undergoing Endoscopy especially those who have gastric or duodenal lesions and other chronic medical problems as its association with these conditions are higher. UGI Endoscopy may be advised to all patients with complaints of persistent pain in upper abdomen because of its precision and relatively safe technique and it also provides diagnosing the pathology, H. pylori infection and its possible therapeutic interventions.

\section{REFERENCES}

1. Alfarouk, Khalid O.; Bashir Adil H.H.; Aljarbou, Ahmed N.; Ramdan, AbdelRahman M.; Muddathir, Abdel Khalig; AlHoufie, Sari T.S.; Hifny, Abdelhamid; Elhassan, Gamal O.; Ibrahim, Muntaser E.; Alqahtani, Saad S.; AlSharari, Shakir D.; Supuran, Claudiu T.; Rauch, Cyril; Cardone, Rosa Angela; Reshkin, Stephan J.; Fais, Stefano; Harguindey, Salvador (22 Febuary 2019). The possible Role of Helicobacter pylori in Gastric Cancer and Its Management. Frontiers in Oncology. 9. doi:10.3389/fonc.2019.00075.

2. Yamaoka, Yoshio (2008). Helicobacter pylori: Molecular Genetics and Cellular Biology. Caister Academic Pr. ISBN 978-1-904455-31-8.

3. Marshall BJ, Warren JR. Unidentified curved bacilli on gastric epithelium in active chronic gastritis. The Lancet. 1983;321 (8336): 1273-5.

4. Marshall BJ, Warren JR. Unidentified curved bacilli in the stomach of patients with gastritis and peptic ulceration. The Lancet. 1984;323 (8390): 1311-5.

5. Sweet, Melissa (2 August 1997;). Smug as a bug. The Sydney Morning Herald. Retrieved 28 January 2007.

6. Alfarouk, Khalid O.; Bashir Adil H.H.; Aljarbou, Ahmed N.; Ramdan, AbdelRahman M.; Muddathir, Abdel Khalig; AlHoufie, Sari T.S.; Hifny, Abdelhamid; Elhassan, Gamal O.; Ibrahim, Muntaser E.; Alqahtani, Saad S.; AlSharari, Shakir D.; Supuran, Claudiu T.; Rauch, Cyril; Cardone, Rosa Angela; Reshkin, Stephan J.; Fais, Stefano; Harguindey, Salvador (22 Febuary 2019). "The possible Role of Helicobacter pylori in Gastric Cancer and Its Management". Frontiers in Oncology. 2019;9(1): 75.

7. Bashir, A. H.; Yousif, S. M.; Hassan, Lamyaa A. M. EL; Elamin, W. M.; Adam, Ameera; Ibrahim, M. E.; Alfarouk, K. O.; Muddhathir, A. K.; Hassan, A. El. Primary Cutaneous Follicular Lymphoma Associated with Helicobacter pylori Infection. American Journal of Dermatology and Venerology. 2013;2 (3): 27-30.

8. Nocturne G, Pontarini E, Bambardieri M, Mariette X (March 2019). Lymphomas complication primary Sjogren's syndrome: from autoimmunity to lymphoma. Rheumatology (Oxford, England). doi:10.1093/ rheumatology/kez052. PNID 30838413.

9. Abbas H, Niazi M, Makker J. Mucosa-Associated Lymphoid Tissue (MALT) Lymphoma of the Colon: A case Report and a Literature Review. The American Journal of Case Reports. 2017;18(5): 491-497.

10. Paydas S. Helicobacter pylori eradication in gastric diffuse large B-cell lymphoma. World Journal of Gastroenterology. 2015;21 (13): 3773-6.

11. Kasznia-Brown J, Karnati G. Imaging of the upper gastrointestinal tract; endoscopy or radiology? Br. J. 
Hosp. Med. (Lond). 2011; 72(3): M39-M43.

12. Alina Boeriu, Cristian Boeriu, Silvia Drasovean. Narrow band imaging with magnifying endoscopy for the evaluation of Gastrointestinal lesion, World Gastrintest Endosc. 2015; 7(2): 100-120.

13. O'Connor $\mathrm{H}$. The role of Helicobacter pylori in peptic ulcer disease. Scand J Gastroenterol Suppl, 1994; 201115.

14. Jia-Qing Huang, Subbaramiah Srichar, Richard H Hunt. Role of Helicobacter pylori infection and nonsteroidal anti-inflammatory drugs in peptic-ulcer disease; a meta-analysis. Lancet 2002; 359(1): 14-22.

15. Richard G Locke III, Nicholas J, Talley et al: Prevalence and clinical spectrum of Gastroesophageal Reflux; a population based study on Olmsted County, Mnnesota, Gastroenterology, 1997; 112(1): 1448-1456.

16. Pounder RE. Ng D. The prevalence of Helicobacter pylori infection in different countries. Aliment. Pharmacol. Ther. 1995;9 (Suppl 2): 33-9.

17. Anurabha S., Milind H.I, Sudharshan: The role of Upper GI Endoscopy in the Diagnosis and Treatment of Chronic Abdominal pain in a Rural Hospital Set Up. New Indian Journal of Surgery, 2018; 9(6): 740-744.

18. Luzza F, Imeneo M, Maletta M: Helicobacter pylori specific $\operatorname{IgG}$ in chronic hemodialysis patients: relationship of hypergastrinemia to positive serology, Nephrol Dial Transplant, 1996; 11(5): 120-124.

19. Khemat $H$, Ahmadzad-Asl M, Amini M: Gastroduodenal lesions and Helicobacter pylori infection in uremic patients and renal transplant recipients. Transplant Poc. 2007; 39(4): 1003-1007.

20. Johannes G, Kuster Arnoud HM, van Vliet and Ernst J. Pathogenesis of Helicobacter pylori infection. KuipersClin. Microbiol. Rev. 2006; 19(3): 449-490.

21. Bauerfeind P, Garner R, Dunn BE and Mobley HL: Synthesis and activity of Helicobacter pylori urease and catalase at low $\mathrm{pH}$. Gut, 1997; 40(1): 25-30

22. Kuwahara H, Miyamoto Y, Akaike T, Kubota T, Sawa T, Okamoto S and Maeda H. Helicobacter pylori urease suppresses bacterial activity of peroxynitrite via carbon dioxide production. Infect. Immun. 2000; 68(3): 43784383.

23. Paronen I, Ala-Kaila K, Rantala I, Kainulainen $\mathrm{H}$ and Karvonen AL. Gastric parietal, chief, and G cell densities in chronic renal failure. Scand.J Gastroenterol, 1991;26(7): 696-700.

24. Fabrizi $\mathrm{F}$ and Martin P. Helicobacter pylori infection in patients with end-stage renal disease. Int. J Artif Organs 2000; 23: 157-164.

25. Sugimoto M, Sakai K, Kita M, Imanishi J and Yakamaoka Y. Prevalence of HP infection in long-term HD patients. Kidney Int 2009; 75(1): 96-103.

26. Chang SS and Hu HY. Lower HP Infection rate in chronic kidney disease and end stage renal disease patients with peptic ulcer disease. J. Clin. Med. Assn. 2014; 77(1): 354-359.

27. Hwang IR, Kodama $T$ and Kikuchi S: Effect of interleukin 1 polymorphisms on gastric mucosal interleukin 1 beta production in Helicobacter pylori infection. Gastroenterology 2002; 123(4): 1793-1803.

28. Ganaye MT and Sheikh JM: Prevalence, endoscopic and histopathological features of HP infection in chronic kidney disease versus normal population at a Tertiary Care Center in North India. Int. J. Adv. Res. 2016; 14(11): 1902-1907.

Source of Support: Nil; Conflict of Interest: None

Submitted: 09-12-2019; Accepted: 02-01-2020; Published online: 13-01-2019 